\title{
Pemerolehan Bahasa Indonesia Sebagai Bahasa Kedua pada Siswa Thailand di MA Nurul Islam Jember
}

\author{
Rosa Yuliana \\ Pendidikan Bahasa dan Sastra Indonesia Universitas Muhammadiyah Jember \\ Rosayllikealways777@gmail.com
}

DOI: http://dx.doi.org/10.32528/bb.v5i1.2989

FDiterima: 08-02-2020

Diterbitkan: 30-03-2020

\begin{abstract}
ABSTRAK
Manusia diberkati sebuah alat yang bernama language acquisition device (LAD) sehingga memungkinkan mereka untuk mampu berbahasa. Begitu pula pemerolehan bahasa yang erat hubungan tentang bagaimana manusia mempresepsi ujaran serta memahami ujaran orang lain, karena memahami serta mempresepsi ujaran adalah unsur pertama untuk menguasai hal dalam berbahasa. Sedangkan pemerolehan bahasa kedua merujuk pada bahasa apapun yang diepelajari seseorang setelah mereka menguasai bahasa ibunya. Studi penelitian ini tentang: (1) bagaimana proses pemerolehan bahasa Indonesia pada pelajar Thailand di MA Nurul Islam, dan; (2) pengimplikasiannya pada aspek sintaksis. Penelitian ini bersifat penelitian kualitatif deskriptif yang nanti akan menguraikan secara terperinci tentang proses pemerolehan bahasa Indonesia pada pelajar Thailand di MA Nuris Islam. Dimana sumber data yang dipakai ialah siswa Thailand itu sendiri. Hasilnya, pemerolehan bahasa Indonesia pada pelajar Thailand telah didapat lebih dulu sebelum tiba di Indonesia, berkat (a) adanya kemiripan antara B1 dengan B2, (b) mempelajari bahasa Indonesia melalui film. Lalu setiba di Indonesia pun pelajar Thailand juga memperoleh bahasa Indonesia dengan adanya, (c) program bimbel untuk pelajar Thailand, dan (d) pemerolehan bahasa dari lingkungan pondok pesantren. Namun dalam implementasiannya dalam aspek sintaksis masih ditemukan (a) ketidak serasian makna kalimat, dan (b) ketidak serasian bentuk. Demikian, dapat disimpulkan bahwa pelajar Thailand ini menguasai bahasa Indonesia sebelum tiba di Indonesia dan mendapatkan wawasan baru berkat program bimbel serta pengaruh lingkungan pondok pesantren. Akan tetapi pengimpelementasiannya dalam aspek sintaksis masih kurang dalam hal makna dan ketidakserasian bentuk kalimat.
\end{abstract}

Kata kunci : Pemerolehan bahasa; bahasa kedua; psikolinguistik 


\begin{abstract}
Humans are blessed with a tool called a language acquisition device (LAD) that enables them to be able to speak. Likewise, acquisition of language is closely related to how humans perceive speech and understand the speech of others, because understanding and perceiving speech is the first element for mastering things in language. Whereas acquisition of a second language refers to whatever language someone learns after they master their mother tongue. This research study is about: (1) how is the process of acquiring Indonesian language in Thai students in MA Nurul Islam, and; (2) its implications on the syntactic aspects. This research is a descriptive qualitative research which will describe in detail the process of acquiring Indonesian language to Thai students in MA Nuris Islam. Where the data source used is Thai students themselves. As a result, the acquisition of Indonesian in Thai students was obtained before arriving in Indonesia, thanks to (a) the similarity between B1 and B2, (b) learning Indonesian through film. Then upon arrival in Indonesia Thai students also obtained Indonesian language through their presence, (c) a tutoring program for Thai students, and (d) language acquisition from the boarding school environment. However, in its implementation in the syntactic aspect it was still found (a) the incompatibility of the meaning of the sentence, and (b) the incompatibility of the form. Thus, it can be concluded that this Thai student mastered Indonesian before arriving in Indonesia and gained new insights thanks to the tutoring program and the influence of the boarding school environment. However, its implementation in the syntactic aspect is still lacking in terms of the meaning and incompatibility of sentence forms.
\end{abstract}

Keywords: Obtaining language; second language; psycholinguistics

\title{
1. PENDAHULUAN
}

Sedari dulu bahasa ditetapkan sebagai alat komunikasi manusia dalam menjalin interaksi dan diturunkan secara genetis. Sebab itu, manusia mampu menjalin komunikasi berkat adanya bahasa yang didapat sejak lahir. Namun, bahasa juga memerlukan proses tumbuh berkembang secara bertahap sesuai usia agar bahasa yang dimiliki lewat hipotesis nurani dapat dikuasai dengan sempurna. Teori ini sejalan dengan pernyataan yang dikemukakan Chomsky dan Miller (dalam Chaer, 2009, hal.169), mereka menyebutkan bahwa sejak manusia pertama kali dilahirkan mereka dikaruniai sebuah alat yang memungkinkan manusia mampu untuk berbahasa. Alat ini bernama language acquisition device (LAD), memudahkan manusia memperoleh bahasa ibunya hingga tingkat bahasa lebih tinggi lagi. Begitu pula pemerolehan bahasa yang erat kaitannya dengan topik tentang bagaimana manusia dapat mempresepsi ujaran serta memahami ujaran orang lain. Dua hal tersebut merupakan unsur pertama wajib dikuasai sebelum manusia mampu berbahasa.

Terjadinya pemerolehan bahasa berlangsung ketika manusia dalam usia 0 hingga 5 tahun. Rentan usia inilah merupakan proses manusia memperoleh bahasa pertama atau bahasa ibunya. Sedangkan pembelajaran bahasa adalah usaha sadar manusia dalam 
proses pengembangan keterampilan guna menguasai bahasa kedua setelah bahasa ibu. Sebab itu sering terjadi polemik tentang pemahaman antara istilah pemerolehan bahasa pertama dengan pemerolehan bahasa kedua. Seperti pendapat Chomsky (dalam Chaer, 2009, hal. 167) yang mengatakan bahwa istilah pemerolehan hanya dikhususkan untuk bahasa pertama, karena bahasa merupakan bawaan manusia sejak lahir. Namun, bahasa kedua terjadi apabila individu telah menguasai bahasa pertama atau dalam proses mengembangkan keterampilan bahasa kedua. Pemerolehan bahasa kedua merujuk pada bahasa apapun yang dipelajari manusia setelah bahasa ibu.

B1 dan B2 memiliki kesamaan dalam proses pemerolehannya. Kesamaan tersebut terletak pada struktur bahasanya yakni kesamaan modus interogasi, negasi, dan morfemmorfem gramatikal. Krashen (dalam Chaer, 2009, hal. 247) juga mengemukakan tentang hipotesisnya yang bahwa bahasa pertama akan mengawali ucapan anak dalam memperoleh bahasa kedua, selagi bahasa keduanya masih belum tampak. Selama belum mampu menguasai bahasa kedua, individu seringkali mentransfer B1 ke dalam B2 ketika menyampaikan suatu gagasan. Pentransferan bahasa ini terjadi pada semua tingkat kebahasaan baik dari tata bunyi, bentuk kata, kalimat, maupun leksikon. Pernyataan ini pula yang menunjukkan struktur dari B1 dengan B2 sama dan mempermudah manusia dalam memperoleh bahasanya yang baru. Jadi, istilah "pemerolehan bahasa kedua" merupakan proses sadar manusia dalam memperoleh bahasa selain bahasa pertamanya baik dipelajari secara alamiah maupun setting formal yang mencakup fonologi, sintaksis, semantik, maupun pragmatik melalui pemerolehan struktur yang sama baik antara B1 ataupun B2, yakni modus interogasi, negasi, dan morfem gramatikal.

Studi tentang pemerolehan bahasa Indonesia sebagai bahasa kedua pada pelajar Thailand menjadi pokok permasalahan dalam penelitian. Penelitian ini terfokus pada deskripsi yang nantinya akan menjelaskan tentang pemerolehan bahasa Indonesia pada pelajar Thailand, serta bagaimana hasil implementasiannya pada aspek sintaksis. Alasan peneliti meneliti tentang rumusan masalah tersebut karena ingin mengetahui bagaimana proses serta tahapan yang telah dilalui pelajar Thailand di MA Nurul Islam dalam memperoleh bahasa Indonesia yang kemudian digunakan dalam komunikasi sehari-hari, baik di lingkungan masyarakat maupun lingkungan persekolahan. Serta, penerapannya dalam menyusun kalimat secara tertulis. Pentingnya penelitian ini dilakukan guna mengetahui tahapan pemerolehan bahasa Indoneisa pada pelajar Tahiland, juga menunjukkan tentang seberapa besar interfensi dari bahasa pertama dalam memperoleh bahasa kedua sebelum diterapkan atau digunakan di lingkungan barunya.

Sebenarnya penelitian tentang pemerolehan bahasa telah dilakukan lebih dulu oleh Maharani dan Astuti tahun 2018. Penelitian ini bertujuan untuk menganalisis struktur sintaksis kalimat pada pelajar darmawisata asing dalam pembelajaran BIPA. Hasil dari penelitian tersebut banyak ditemukan error performasi struktural baik dalam tataran sintaksis ataupun morfologis yang menjadi indikator pertama dalam pembelajaran. Hal yang menjadi pembeda dengan penelitian sebelumnya ialah terletak pada subjek penelitian. Jika penelitian terdahulu menggunakan sumber dari darmasiswa asing dalam pembelajaran BIPA, sedangkan sumber penelitian ini adalah pelajar 
Thailand yang sedang berlajar di Indonesia. Selain itu tujuan dari penelitian sebelumnya berupa studi kasus yang menganalisis tentang struktur sintaksis kalimat darmasiswa. Namun, penelitian ini memiliki dua tujuan yakni mengetahui proses atau tahapan pemerolehan bahasa Indonesia pada pelajar Thailand dan pengimplementasiannya dalam aspek sintaksis kalimat dalam bentuk bahasa tulis.

\section{METODE PENELITIAN}

Penelitian ini masuk ke dalam jenis penelitian kualitatif deskriptif, yang nantinya hasil data penelitian disajikan dalam bentuk uraian terperinci tentang proses pemerolehan bahasa Indonesia pada pelajar Thailand di MA Nuris Islam dan hasil implementasinya dalam aspek sintaksis.

Seperti paparan di bagian sebelumnya, data penelitian ini berupa transkrip hasil rekaman wawancara antara peneliti dengan sumber data tentang uraian rinci yang menjelaskan tentang tahap pemerolehan bahasa Indonesia pada pelajar Thailand. Selain itu, berupa data dokumentasi yang menunjukkan hasil implementasi pemerolehan bahasa Indonesia yang telah diperoleh dalam aspek sintaksis. Sedangkan sumber data penelitian ini ialah beberapa pelajar dari Thailand yang masih tercatat sebagai siswa aktif di MA Nurul Islam Jember. Data yang digunakan untuk dianalisis nantinya berupa rekaman yang telah ditranskrip ke dalam bentuk bahasa tulis yang berisi percakapan antara peneliti dengan sumber data. Lalu hasil dokumentasi berupa karangan pendek yang dibuat oleh pelajar Thailand sebagai sumber data dalam penelitian.

Terdapat dua teknik pengumpulan data yang digunakan dalam penelitian ini. Pertama ialah metode cakap dengan teknik lanjutan cakap semuka. Teknik ini akan dibantu dengan dua teknik lanjutan lainnya, yakni teknik lanjutan rekam dan teknik lanjutan catat. Nantinya pada praktik sesungguhnya di lapangan, peneliti akan bertatap muka dan melakukan tanya jawab dengan sumber data terkait dengan masalah penelitian. Peneliti juga menggunakan metode instropektif sebagai metode yang menyediakan data dengan memanfaatkan intuisi peneliti tentang bahasa ibu yang telah dikuasainya. Kemudian, teknik pengumpulan data yang kedua adalah metode simak dengan teknik sadap untuk memperoleh penggunaan bahasa secara tertulis.

Mahsun (2014, hal.117) menyatakan bahwa analisis data adalah tahapan yang menentukan hasil data yang diperoleh sehingga memunculkan kesimpulan atas pokok permasalahan yang dicari. Pengolahan atau penganalisisan data pada penelitian ini dilakukan setelah seluruh data yang dibutuhkan cukup dan telah lengkap. Langkah selanjutnya peneliti akan mencari, menemukan pola, dan mengelola data sehingga mendapatkan hasil yang terstuktur dan sistematis tentang tahapan pemerolehan bahasa Indonesia pada pelajar Thailand di MA Nuris Islam Jember serta implementasinya dalam aspek sintaksis. Metode padan intralingual merupakan metode yang digunakan dalam menganalisis data yang telah diperoleh. Teknik lanjutan yang dipakai ialah teknik hubung banding menyamakan hal pokok (HBSP), teknik ini dipakai guna menemukan kesamaan dari bahasa Indonesia yang menjadi pembanding untuk menyamakan bahasa ibu milik pelajar Thailand. 
Setelah data dianalisis maka perlu ditetapkan keabsahannya. Pengujian keabsahan ini merupakan tindakan mengkonfirmasi kembali data yang diperoleh. guna menghindari ketidakvalidan atau ketidaksesuaian antara tujuan dengan hasil penelitian, sehingga data yang diperoleh bisa dipertanggung jawabkan kesahihannya. Teknik pengujian keabsahan data yang digunaka peneliti adalah dengan pengecekan teman sejawat, atau melalui diskusi. Nantinya, peneliti akan mengkonsultasikan keabsahan data yang diperoleh kepada ibu dosen pembimbing.

\section{HASIL DAN PEMBAHASAN}

Pembahasan dalam penelitian ini berupa (a) proses pemerolehan bahasa Indonesia pelajar Thailand, dan (b) implikasi analisis sintaksis. Data dalam penelitian ini merupakan data awal yang didapat oleh peneliti, yang memungkinkan akan ada data lainnya sebagai pelengkap pada penelitian selanjutnya.

\section{A. Proses Pemerolehan Bahasa Indonesia Pelajar Thailand}

Sebelum tiba di Indonesia, anak-anak Thailand yang sedang menempuh studinya di Indonesia ini telah melewati proses sehingga mereka mampu menguasai bahasa Indonesia. Setiba di Indonesia pun mereka mulai beraktivitas di sekolah, dan semakin menemukan banyak hal baru yang menambah wawasan pengetahuannya dalam menguasai bahasa Indonesia. Proses pemerolehan tersebut diantaranya, (1) adanya kemiripan antara B1 dengan B2, (2) mempelajari bahasa Indonesia dari film dan musik Indonesia, (3) program bimbel di MA Nurul Islam untuk pelajar Thailand, dan (4) pemerolehan bahasa di lingkungan pondok pesantren.

1) Adanya kemiripan antara $B 1$ dan $B 2$

Thailand merupakan Negara yang terbagi menjadi enam kelompok wilayah berbeda. Sistem dengan enam wilayah ini dikembangkan pada tahun 1978 oleh Komite Nasional Geografi. Pembagian wilayah tersebut dicetuskan pertama kali oleh Dewan Riset Nasional Kerajaan Thai. Sitem ini membagi negara Thailand menjadi Thailand Utara, Thailand Timur Laut, Thailand Barat, Thailand Pusat, Thailand Timur, dan Thailand Selatan. Kawasan Thailand Selatan berbatasan langsung dengan Semenanjung Malaysia yang mayoritas penduduknya merupakan masyarakat Melayu dan beragama Islam. Hal tersebut menjadi faktor utama yang memungkinkan bahasa pertama dari penduduk Thailand, khususnya Thailand Selatan ini bukanlah bahasa Thai, melainkan bahasa Melayu.

Bahasa Melayu dan bahasa Indonesia merupakan dua bahasa berbeda namun memiliki kemiripan dalam makna dan struktur kata serta kalimatnya. Hanya saja perbedaan diantara dua bahasa ini terletak pada cara pengucapan, proses pembentukan fonologi dan morfologisnya.

(1)

Bahasa Melayu Thailand : Nok kimano?

Bahasa Indonesia : Mau kemana? 
$\begin{array}{ll}\text { Bahasa Melayu Thailand } & \text { : Aku nok make. } \\ \text { Bahasa Indonesia } & \text { : Saya mau makan. }\end{array}$

Bahasa Melayu Thailand : Aku nok gi koloh.

Bahasa Indonesia :Saya mau pergi ke sekolah.

Data 1 dan data 2 merupakan hasil transkrip wawancara yang telah dilakukan peneliti pada sumber data bernama Firdaus yang berasal dari wilayah Yala, Thailand Selatan. Dari dua data tersebut serta penjelasan sumber data yang mengatakan bahwa ciri khas dari bahasa Melayu di Thailand Selatan ialah pengejaan huruf [a] di akhir kosa kata pada bahasa Indoneseia berubah dan dibaca [e] atau [o] pada bahasa Melayu Thailand.

Dari hasil wawancara yang telah dilakukan, dipaparkan bahwa sumber data memahami petuturan bahasa Indonesia berkat adanya kemiripan bahasa antara bahasa Melayu yang merupakan bahasa pertama dari sumber data dengan bahasa Indonesia. Selain itu terdapat faktor lain yang menjadi interfensi sebagai penjelasan alasan mengapa sumber data tersebut mampu berbahasa Indonesia. Faktor tersebut ialah sumber data yang memiliki beberapa sanak saudara yang berasal dari Indonesia, kemudian ada pula masyarakat Indonesia yang tinggal menetap di lingkungan rumahnya. Sehingga, sering kali muncul ucapan-ucapan bahasa Indonesia yang terdengar olehnya. Sebab itu sumber data menjelaskan bahwa ucapan yang ia dengar memiliki kemiripan dengan bahasa Melayu sehingga ia mampu memahami bahasa Indonesia sedikit demi sedikit.

Pada hasil data ini, analisis mengacu pada teori Robins (1992, hal. 416) yang mengungkapkan bahwa perbedaan bahasa dapat terjadi akibat adanya pemisahan secara geografis, tetapi perbedaan-perbedaan yang terjadi hanya bersifat dialektis. Akan tetapi secara historis bahasa diturunkan dari bahasa sebelumnya. Kata-kata tertentu dalam suatu bahasa yang dimaksud diturunkan dari kata-kata tertentu dari bahasa sebelumnya juga. Sebagai contoh, bahasa Perancis diturunkan dari bahasa Latin, maka dikatakan bahwa bahasa Perancis merupakan bahasa yang bentuknya telah dipengaruhi oleh bahasa Latin dalam suatu geografis tertentu dan dalam kurun waktu tertentu. Begitu pula dengan bahasa Indonesia yang berasal dari bahasa Melayu, kedua bahasa tersebut masuk ke dalam rumpun bahasa Austronesia.

\section{2) Mempelajari bahasa Indonesia dari film}

Pemerolehan suatu bahasa bisa didapat melalui berbagai cara, salah satunya dengan film. Film merupakan media paling cepat bagi manusia untuk memperoleh bahasa baru. Film bisa berperan sebagai sarana hiburan sekaligus pembelajaran suatu bahasa baru bagi para penonton. Firdaus, salah satu siswa Thailand di MA Nurul Islam juga mengatakan bahwa ia mulai mampu memahami bahasa Indonesia berkat film-film Indonesia yang sering ditontonnya. Hasil penelitian ini sejalan dengan teori yang 
dikemukakan Skinner yang menganggap bahwa bahasa bisa muncul akibat adanya stimulus - respon antara petutur dan pendengar. Skinner mengungkap tentang pemerolehan bahasa bisa melalui perilaku respon operan, terutama pada respon perilaku yang kedua yakni echoic merupakan pemerolehan respon berupa pola bunyi bahasa yang setara atau mirip dengan stimulusnya. Maka, jika diartikan bila seseorang berperan sebagai responden yang akan memperoleh atau mempelajari suatu bahasa baru, ia akan menirukan ucapan-ucapan dari stimulusnya, yang disini berasal dari tuturan dalam film yang ditonton oleh sumber data.

Bahkan, akibat faktor seringnya Firdaus menonton film-film Indonesia ia semakin menguasai bahasa Indonesia. Dibantu dengan adanya translate bahasa melayu pada film yang ditonton membuat sumber data ini memahami arti serta bentuk pengucapan bahasa Indonesia. Sehingga, ketika tiba di Indonesia dan menjadi pelajar di MA Nurul Islam, ia tidak kaget ataupun terkejut akan bahasa Indonesia yang ia dengar.

Pemerolehan suatu bahasa melalui pemanfaatan media film ini dikarenakan banyaknya individu yang lebih senang belajar melalui suatu media yang bersifat menghibur. Keberadaan film-film Indonesia inilah memiliki peran yang besar dalam pemerolehan suatu bahasa tertentu, karena dengan film individu dapat mengoptimalkan pendengaran, serta menirukan ujaran-ujaran yang akan menambah kosakatanya (Widia, tanpa tahun, hal. 9).

\section{3) Program bimbel untuk pelajar Thailand di Indonesia}

Setiap tahunnya, pelajar Thailand selalu datang ke Indonesia sebagai pertukaran pelajar yang akan menimba ilmu di yayasan Nurul Islam. Hal tersebut telah menjadi program kerja sama antara pihak yayasan dengan pemerintahan dari Thailand Selatan. Maka dari itu, yayasan ini tak terkecuali MA Nurul Islam pun selalu membentuk bimbingan belajar setiap tahunnya selama satu bulan di awal tahun ajaran bagi anakanak Thailand yang sedang mengemban ilmu di MA Nurul Islam. Menurut hasil wawancara yang telah dilakukan, sumber data mengatakan bahwa program bimbingan belajar berlangsung setelah jam sekolah usai. Meskipun beberapa sumber data lain yang telah diwawancari mengakui bahwa mereka telah mengerti bahasa Indonesia, namun dengan adanya program bimbingan belajar yang diadakan sekolah semakin membuat pelajar Thailand memahami akan kosa kata-kosa kata baru dari bahasa Indonesia. Salah satu sumber data mengatakan bahwa setiba di Indonesia dia mulai mengerti bahwa ada banyak macam kata persamaan (sinonim) yang belum ia ketahui dan sulit dipahami. Begitu pula dengan istilah-istilah serapan yang ada dalam bahasa Indonesia. Dua hal tersebut pula yang menjadi kesulitan baru yang musti dihadapi Firdaus bersama temantemannya yang lain ketika belajar bahasa Indonesia.

\section{4) Pemerolehan bahasa dari lingkungan pondok pesantren}

Lingkungan memiliki pengaruh besar terhadap perilaku anak begitu pula dalam hal penguasaan bahasa. Dengan bekal pemahaman bahasa Indonesia yang telah dimiliki berkat adanya kemiripan bahasa antara B1 dan B2, dan program bimbingan belajar bahasa Indonesia yang dibuat oleh sekolah. Para pelajar Thailand ini pun memperoleh 
dan semakin memperluas pengetahuannya tentang bahasa Indonesia berkat lingkungan pondok pesantren yang menjadi tempat tinggal selama menimba ilmu di MA Nurul Islam. Interaksi komunikasi yang dilakukan setiap waktu dengan teman pesantren yakni pelajar asli dari penduduk Indonesia membuat pelajar Thailand memiliki lebih banyak lagi kosa kata dan istilah-istilah baru. Bahkan, para pelajar Thailand ini khususnya mereka yang telah lama di Indonesia yakni siswa kelas XII mulai memahami dan menirukan bahasa daerah dari teman sepesantrenannya yakni bahasa Madura. Kemungkinan akan menjadi B3 bagi pelajar Thailand jika mereka semakin menguasai keseluruhan dari bahasa daerah milik penduduk lokal sekitar MA Nurul Islam.

Pemerolehan bahasa bisa tidak hanya terjadi secara internal individu saja, namun juga bisa dikendalikan dari luar yakni rangsangan yang diperoleh dari lingkungan sekitar. Kaum behaviorisme pun menyebutkan kemampuan memahami suatu bahasa seseorang diperoleh akan adanya rangsangan dari lingkungan sekitar. Anak berperan sebagai penerima pasif dari tekanan lingkungannya dalam memperoleh suatu bahasa. Rangsangan (stimulus) dari lingkungan tersebut dapat memperkuat kemampuan berbahasa dari anak, maka dapat dikatakan bahwa kemampuan anak dalam berkomunikasi dan memperoleh bahasa juga melalui prinsip pertalian S-P (stimulusrespons) dan proses peniruan-peniruan dari lingkungan yang ada disekitar anak (Ahmadi \& Jauhar, 2015, hal. 179).

\section{B. Implikasi Analisis Sintaksis}

Setelah pelajar Thailand telah menguasai bahasa Indonesia, selanjutnya hasil pencapaian tersebut akan diuji melalui empat kecakapan berbahasa khususnya dalam hal menulis. Menulis merupakan kecakapan berbahasa ditingkat paling akhir. Nantinya, pelajar Thailand akan diuji sejauh mana mereka mampu mengimplikasikan bahasa Indonesia yang telah diperolehnya dalam bentuk tulisan berupa karangan cerita bebas. Hasil karangan tersebut akan dianalisis dan di cek keserasian unsur-unsur kalimatnya, diantaranya (1) keserasian makna, dan (2) keserasian bentuk.

1) Keserasian unsur-unsur kalimat

Kalimat merupakan satuan bahasa yang memiliki kontruksi besar, terdiri dari satu kata, dua kata, atau lebih. Walaupun kalimat bisa diuraikan kembali menjadi untaian kata, akan tetapi penguraian tersebut tidak merta dari kalimat ke kata. Satuan-satuan yang membentuk kontruksi tersebut disebut konstituen. (Putrayasa, 2017, hal. 44).

Begitu pula dalam menggabungkan dua kata atau lebih pada kalimat yang selalu menutut adanya keserasian antara unsur-unsur tersebut. penggabungan tersebut haruslah serasi baik segi makna dan segi bentuk. Keserasian unsur-unsur kalimat tersebut akan diuraikan dalam hasil data dan pembahasan berikut ini.

a) Keserasian makna kalimat

\section{KMK 1}

"Saya bisa tahu Indonesia itu seperti apa. Banyak dengan kebudayaan, dalam beberapa bahasa, dalam beberapa perbedaan tapi Indonesia tidak dipecah belah."

Koreksi : 
"Saya bisa tahu Indonesia itu seperti apa. Banyak kebudayaan, bahasa yang berbedabeda tetapi Indonesia tidak terpecah belah."

\section{KMK 2}

"Semua itu dapat saya ada kepercayaan walau kita ada beberapa perbedaan tapi kita bisa bersatu."

Koreksi :

"Semua itu saya percaya walau kita memiliki perbedaan tetapi kita bisa bersatu."

Terdapat ketidak sinkronan penyusunan dalam pola kalimat pada data KMK 1 . Ketidak sinkronan tersebut disebabkan oleh adanya keterangan banyak dengan diikuti subjek kebudayaan setelah itu muncul keterangan dalam beberapa dan diikuti kembali subjek bahasa hingga akhir kalimat ditutup dengan predikat dipecah belah. Kata keterangan boleh diletakkan di awal kalimat namun harus diikuti subjek dan predikat yang tidak dipisah-pisah oleh koma. Selain itu susunan kalimat pada data KMK 1 terasa aneh karena terlalu banyak kata keterangan setelah koma sehingga muncul kekaburan makna dari kalimat yang ditulis. Namun, koreksi kalimat pada data KMK 1 dibawahnya nampak bahwa penulis yang hendak menerangkan bahwa Indonesia memiliki banyak perbedaan budaya dan bahasa namun tetap bisa bersatu.

Ketidak serasian makna pun juga terjadi pada data KMK 2. Kata dapat dan konfiks ke-an pada kepercayaan menjadi pengganggu susunan kalimat data KMK 2. Kata kepercayaan yang diturunkan dari verba bentuk akar yakni percaya berubah menjadi nomina dari asal klausa 'saya percaya' setelah menfapat konfiks ke-an. Kemudian keberadaan frasa ada beberapa tidak sinkron bila disandingkan dengan kata selanjutnya. Sehingga, agar makna tidak kabur dan pesan bisa tersampaikan maka perlu dihilangkannya frasa tersebut agar keserasian makna tetap. Melihat koreksi kalimat pada data KMK 2 dibawahnya menerangkan bahwa nomina saya, percaya walau memiliki perbedaan tetapi tetap bisa bersatu.

Dari hasil dua data keserasian makna pada KMK 1 dan KMK 2 menegaskan bahwa kaidah bahasa tidak sama dengan kaidah susunan kenyataan menurut pengalaman dan pengertian kita. Keluwesan kaidah bahasa justru memungkinkan pembahasan apa saja termasuk keadaan dan peristiwa serba aneh. (Putrayasa, 2017, hal. 47). Tampak kalimat dari data KMK 1 dan KMK 2 tidak bisa diterima karena susunan gramatikalnya masih salah sehingga terjadi kekaburan pada maknanya Ketidakserasian makna juga ada pada penelitian sebelumnya milik Maharani \& Astuti (2018, hal. 129) akibat adanya kesalahan-kesalahan muncul ketika dalam memproduksi kalimat dinilai dari ketepatan pemilihan afiksasi dalam verba dan penulisan frasa.

b) Keserasian bentuk kalimat

\section{KBK 1}

"Saya rasa pengalaman yang saya pernah menghadapi bisa jadi pelajaran bagi saya." 
Koreksi :

"Saya rasa pengalaman yang pernah saya hadapi bisa jadi pelajaran bagi saya."

Kesalahan penggunaan konfiks me-i pada kata menghadapi. Bila kata tersebut mendapat konfiks me-i terasa kurang tepat karena sesungguhnya penggunaan konfiks tersebut berkategori ganda yakni ajektiva dan verba. Ajektiva ini perlu didahului oleh adverbial 'agak' atau 'sangat' dan sebagai verba juga perlu diikuti sebuah objek agar memberikan makna yang sesuai. Namun karena kurang tepatnya penggunaan afiksasi pada data KBK 1 dapat menimbulkan kesalahan makna akibat kurangnya keserasian bentuk kalimat yang digunakan. Seperti pada kalimat yang telah dikoreksi pada bagian bawah data KBK 1, kata hadap lebih tepat menggunakan sufiks -i $\neg$ agar memiliki makna gramatikal telah merasa pada sesuatu. Sesuai dengan makna gramatikalnya bahwa kata saya sebagai pelaku pada data KBK 1 hendak menerangkan ia merasa bahwa pengalaman yang telah didapatnya memiliki pesan yang bisa menjadi pelajaran pada hidupnya.

Keserasian dari sebuah kalimat tidak hanya menuntut akan adanya keserasian makna secara bahasa Indonesia yang benar namun juga bentuk di antara unsur-unsur kalimat yang dibuat. Khususnya pemilihan afiksasi untuk menghubungkan nomina dan pronominal, nomina dan verba, dan lain sebagainya (Putrayasa, 2017, hal. 47).

Setelah membahas seluruh hasil temuan data serta ulasan yang dilakukan, bisa dipahami bahwa pemerolehan setelah bahasa ibu adalah kegiatan yang melibatkan kemampuan berbahasa yang ada di dalam otak manusia. Sekalipun individu tersebut merasa telah menguasai bahasa Indonesianya namun belum tentu keempat kemampuan berbahasa juga telah dikatakan sempurna. Mengingat bahwa kemampuan menulis merupakan tingkatan berbahasa yang berada di atas dan yang paling sulit. Dari hasil data yang telah dipaparkan bisa dibutkikan masih terdapat eror atau kesalahankesalahan dalam menyampaikan pesan melalui tulisan. Kesalahan yang terjadi tidak hanya terjadi pada tataran sintaksis namun juga penggunaan morfologisnya. Sehingga, pesan yang ingin diutarakan tidak tersampaikan seluruhnya atau hanya sebagian. Bahkan bisa juga menimbulkan kekaburan makna dan pesan tidak dapat tersampaikan.

\section{KESIMPULAN}

Istilah penguasaan pada bahasa kedua terjadi apabila anak telah menguasai bahasa pertama yang kedepannya akan menjadi bekal dalam proses mengembangkan keterampilan bahasa keduanya. Pernyataan tersebut hendak menegaskan bahwa dimana pun anak memperoleh bahasa kedua, ketiga, dan seterusnya dengan memakai strategi yang sama karena bahasa ibu yang telah dikuasai menjadi bekal dalam memperoleh bahasa selanjutnya. Begitu pula dengan pertukaran pelajar asing menuntut anak atau individu untuk menguasai bahasa dari Negara yang dituju.

Dari hasil data dan pembahasan yang telah dilakukan menunjukkan bahwa para pertukaran pelajar yang sedang melalukan studinya di MA Nurul Islam memperoleh dan mampu menguasai bahasa Indonesia dengan baik akibat adanya faktor kesamaan bahasa 
ibu yang dikuasainya yakni dengan bahasa Melayu dengan bahasa Indonesia yang dipelajarinya sebagai bahasa kedua. Selanjutnya penguasaan bahasa Indonesia juga dibantu dengan menggunakan media film. Akibat adanya stimulus dan respon yang muncul membuat anak berulang kali menirukan percakapan yang ada di dalam film semakin membantu pelajar Thailand menguasai bahasa Indoneisa dengan cepat. Setiba di Indonesia pun penguasaan bahasa pelajar Thailand ini diasah dengan dibantu dengan program bimbingan belajar yang dibuat instansi sekolah selama dua bulan serta keberadaan lingkungan pondok pesantren yang menjadi tempat tinggal individu. Dua proses tersebut juga membuat anak memiliki banyak lagi wawasan dan kosa kata-kosa kata baru dalam bahasa Indonesia. Bahkan peluang pemerolehan bahasa ketiga pun muncul karena pengaruh lingkungan yang kuat terhadap pemerolehan bahasa pada anak. Namun meskipun kemampuan menyimak, berbicara dan menulis pelajar Thailand sudah dikuasai cukup baik akan tetapi penguasaan bahasa Indonesia mereka dalam aspek sintaksis mereka terbilang belum bisa dikatakan sempurna. Dari hasil karangan yang dibuat dan dijadikan sebagai data penelitian, hasilnya masih terdapat kesalahan penyusunan kalimat dan penggunaan afiksasi. Sehingga kalimat yang dibuat tidak memiliki keserasian baik secara makna dan bentuk.

\section{DAFTAR RUJUKAN}

Ahmad \& Alek. 2016. Bahasa Indonesia untuk Perguruan Tinggi: subtansi kajian dan penerapannya. Jakarta: Penerbit Erlangga.

Ahmadi, A \& Jauhar, M. (2015). Dasar-Dasar Psikolinguistik. Jakarta: Prestasi Pustakaraya.

Bungin, B. 2011. Penelitian Kualitatif: komunikasi, ekonomi, kebijakan publik, dan ilmu sosial lainnya (Edisi Kedua). Jakarta: Kencana Prenada Media Group.

Chaer, A. 2009. Psikolinguistik: Kajian Teoritik. Jakarta: Rineka Cipta.

Dardjowidjojo, S. (2005). Psikolinguistik: Pengantar Pemahaman Bahasa Manusia. Jakarta: Unika Atma Jaya.

Jalal, M. (2012). Kekerabatan Bahasa-Bahasa Minahasa di Propinsi Sulawesi Utara. Litera, 11(2).

Lestari, N., \& Nastiti, D. (2014). Analisis Kesamaan Rumpun Bahasa BI dan Malagasi sebagai Alat Bantu Proses Pembelajaran Bahasa Indonesia Bagi Penutur Asing (BIPA). Mabasan, 8(2).

Maharani, T., \& Astuti, E. S. (2018). Pemerolehan Bahasa Kedua dan Pengajaran Bahasa dalam Pembelajaran BIPA. Jurnal Bahasa Lingua Scientia, 10(1), 121-142.

Mahsun. 2005. Metode Penelitian Bahasa Tahapan Strategi, Metode, dan Tekniknya. Jakarta: PT Rajagrafindo Persada. 
Mahsun. (2014). Metode Penelitian Bahasa: Tahapan Strategi, Metode, dan Tekniknya (Edisi Revisi). Jakarta: Rajagrafindo Persada.

Prastowo, A. (2011). Metode Penelitian Kualitatif dalam Prespektif Rancangan Penelitian. Jogjakarta: AR-Ruzz Media.

Putrayasa, B., I. (2012). Jenis Kalimat dalam Bahasa Indonesia. Bandung: Refika Aditama.

Putrayasa, B., I. (2017). Sintaksis memahami Kalimat Tunggal. Bandung: Refika Aditama.

Robins, H., R. (1992). Linguistik Umum Sebuah Pengantar. Yogyakarta: Kanisius (anggota IKAPI).

Sudaryanto. (2015). Metode dan Aneka Teknik Analisis Bahasa. Yogyakarta: Sanata Dharma University Press.

Syamsiyah, D. (2017). Analisis Deskriptif Teori Pemerolehan Bahasa Kedua. Journal Al-Manar, 6(2).

Widia, I. (tanpa tahun). Media pembelajaran bahasa indonesia penutur asing. 